\title{
Recent Progress in Flexible Perovskite Solar Cell Development
}

\author{
Xiaodong Ren and Hyun Suk Jung ${ }^{\dagger}$ \\ School of Advanced Materials Science \& Engineering, Sungkyunkwan University, Suwon 16419, Korea
}

(Received April 27, 2018; Revised June 10, 2018; Accepted June 19, 2018)

\begin{abstract}
Perovskite solar cells (PSCs) are a new class of photovoltaic devices, which have attracted significant attention due to their remarkable optoelectrical properties, including high absorption coefficients, high carrier mobilities, long carrier diffusion lengths, tunable bandgaps, low cost, and facile fabrication. PSCs have reached efficiencies of $22.70 \%$ and $18.36 \%$ on rigid fluorine-doped tin oxide and poly(ethylene terephthalate) substrates, respectively; these are comparable to those of single-crystal silicon and copper-indium-gallium-selenium solar cells. Over the past eight years, the photo conversion efficiency of PSCs has been significantly improved by device-architecture adjustments, and absorber and electron/hole transport layer optimization. Each layer is important for the performance of PSCs; hence, we discuss achievements in flexible perovskite solar cells (FPSCs), covering electron/holetransport materials, electrode materials. We give a comprehensive overview of FPSCs and put forward suggestions for their further development.
\end{abstract}

Key words : Perovskite solar cells, Flexibility, Metal oxide

\section{Introduction}

$D^{\mathrm{u}}$ ue to their excellent optoelectrical properties, such as long diffusion lengths, strong absorptivity, high carrier mobilities, low defect densities, and tunable bandgaps, perovskites have drawn significant attention as promising alternative absorber materials for optoelectronic devicesespecially for use in perovskite solar cells (PSCs), where the efficiency has risen to $22.70 \%{ }^{1)}$ (certified) and $18.36 \%^{2)}$ on rigid-glass and flexible-polymer substrates, respectively. This is comparable to the efficiencies of single-crystal silicon and copper-indium-gallium-selenium (CIGS) solar cells. Recently, numerous studies of these materials have been published. The typical structure of a PSC is a transparent conducting oxide (TCO) substrate followed by an electrontransport layer (ETL), the perovskite, a hole-transport layer (HTL), and a metal electrode. The recent increase in efficiency is ascribed to modifications to the device structure and optimization of the material compositions.

Perovskite materials were originally used as a sensitizer in dye-sensitized solar cells. Miyasaka's group employed a $\mathrm{CH}_{3} \mathrm{NH}_{3} \mathrm{PbBr}_{3}$ sensitizer and obtained an efficiency of $3.8 \%{ }^{3)}$ However, $\mathrm{CH}_{3} \mathrm{NH}_{3} \mathrm{PbBr}_{3}$ was very unstable in iodidecontaining liquid electrolytes, which causes the device to degrade rapidly. In 2011, Park's group fabricated quantumdot-sensitized solar cells using pre-synthesized perovskite materials of $2-3 \mathrm{~nm}$ in diameter. A photoconversion efficiency (PCE) of $6.54 \%$, attributed to the high absorptivity of

\footnotetext{
${ }^{\dagger}$ Corresponding author: Hyun Suk Jung

E-mail : hsjung1@skku.edu

Tel : +82-31-290-7403 Fax : +82-31-290-7410
}

the $\mathrm{CH}_{3} \mathrm{NH}_{3} \mathrm{PbI}_{3}$ quantum dots and the low current loss of the thin $\mathrm{TiO}_{2}$ film, was achieved. ${ }^{4}$ In 2012 , Park et al. fabricated solid-state, sensitized, heterojunction perovskite solar cells for the first time (device structure: fluorine-doped tin oxide (FTO), $\mathrm{TiO}_{2}$ blocking layer, mesoporous $\mathrm{TiO}_{2}$ perovskite, 2,2',7,7'-tetrakis (N,N-di-pmethoxyphenylamine)9,9'-spirobifluoren (spiro-OMeTAD), Au); the highest efficiency, $9.7 \%$, was obtained by optimizing the layer thicknesses. The most important development was a remarkable improvement in device stability: it was air stable for over $500 \mathrm{~h}$ without encapsulation. ${ }^{5}$ ) This is a milestone for PSC development, enabling further performance improvements. As it achieves a high PCE, this structure has been widely adopted by other researchers.

Another breakthrough, achieved by Snaith's group, was the development of low-cost, solution-processable PSCs with a PCE of 10.9\%; this was the highest PSC PCE then measured. In their study, $\mathrm{TiO}_{2}$ was replaced with insulating mesoporous $\mathrm{Al}_{2} \mathrm{O}_{3}$. . They also revised understanding of PSC device structures by proposing a new PSC structure, known as the planar structure. Their results showed that nanostructuring is not required to achieve high PSC efficiencies. They prepared a $\mathrm{CH}_{3} \mathrm{NH}_{3} \mathrm{PbI}_{3-\mathrm{x}} \mathrm{Cl}_{\mathrm{x}}$ perovskite film by dualsource evaporation and sandwiched this between a planar ETL and a planar HTL; the PCE of this system reached $15.4 \%$, with a $\mathrm{V}_{\mathrm{oc}}$ of $1.07 \mathrm{~V}$, a $\mathrm{J}_{\mathrm{sc}}$ of $21.5 \mathrm{~mA} \mathrm{~cm}^{-2}$, and an $\mathrm{FF}$ of $0.67 .^{7)}$ Now, PSC structures are divided into two categories: mesoporous and planar.

Many strategies for PSC fabrication have been introduced, with the aim of improving PSC performance-these include solvent engineering, ${ }^{8,9)}$ employment and doping of new transport materials, ${ }^{10-13)}$ addition of additives in the 
perovskite film, ${ }^{14)}$ interface engineering, ${ }^{15)}$ tuning the perovskite film composition, ${ }^{16)}$ and various different preparation techniques. ${ }^{17,18)}$ Current state-of-the-art PSC efficiencies are $22.70 \%$ and $19.70 \%$ with active areas of $0.095 \mathrm{~cm}^{2}$ and $1.0 \mathrm{~cm}^{2}$, respectively; these are obtained using $\left(\mathrm{FAPbI}_{3}\right)_{1-\mathrm{x}}$ $\left(\mathrm{MAPbBr}_{3}\right)_{\mathrm{x}}$ mixed perovskite films as absorbing layers. $\left.{ }^{19}\right)$ However, most high-efficiency PSCs utilize rigid substrates, which are heavy, inflexible, and fragile. Flexible PSCs for large-area, modular devices can be easily fabricated using the roll-to-roll technique and easily match the shapes of portable electronic products. ${ }^{20)}$ Due to these benefits, flexible PSCs are an active area of research. Several types of flexible solar cells have been reported, including: silicon-based flexible solar cells, for example silicon-based thin-film solar cells; ${ }^{21-24)}$ compound flexible solar cells, such as CIGS, ${ }^{25,26)}$ and CdTe, ${ }^{27,28)}$ organic solar cells; ${ }^{29-31)}$ dye-sensitized solar cells $;^{32,33)}$ and organic-inorganic hybrid solar cells, for example perovskite solar cells. ${ }^{13,34)}$ In this review, we will cover recent progress in the field of flexible perovskite solar cells. A typical PSC device consists of five key components: the TCO substrate, ETL, active perovskite layer, HTL, and rear electrode. PSC device structures are classified into regular and inverted planar structures, based on their stacking sequence. In this review, we will cover the state-of-the-art in flexible PSCs (FPSCs) from the viewpoint of the aforementioned cell structures and components.

\section{Flexible Perovskite Solar Cells}

The exhilarating results have been achieved for most of the popular solar cells based on the rigid substrates. However, rigid substrates have numerous drawbacks, such as their weight, frangibility, and rigidity, which prevent them from satisfying the demands of modern flexible electronic devices; as flexible solar cells do not possess these drawbacks, they have attracted significant attention.

As they are solution processable and have low fabrication temperatures $\left(<150^{\circ} \mathrm{C}\right)$, simple structures, and high efficiencies, FPSCs have a promising future. In recent years, there has been significant progress in FPSC technology, with PCEs of up to $18.40 \%$ achieved, ${ }^{35)}$ hugely exceeding the PCEs of other flexible solar cells. FPSC devices have the same structure as rigid devices, and can also be divided into planar and mesoporous architectures. In the following sections, recent advances in FPSC ETLs, HTLs, and electrodes will be discussed.

\subsection{FPSCs based on planar architectures}

Transparent polyethylene terephthalate (PET) and polyethylene naphthalate $(\mathrm{PEN})$ polymers coated with indium tin oxide (ITO) are widely used flexible substrates. The main drawback of this type of flexible, conductive substrate is that they cannot withstand high-temperature annealing $\left(>150^{\circ} \mathrm{C}\right)$. However, most high-PCE PSC devices are based on $\mathrm{TiO}_{2}$ ETLs, particularly mesoporous structures; in this case, a high temperature $\left(>450^{\circ} \mathrm{C}\right)$ annealing process is still (a)

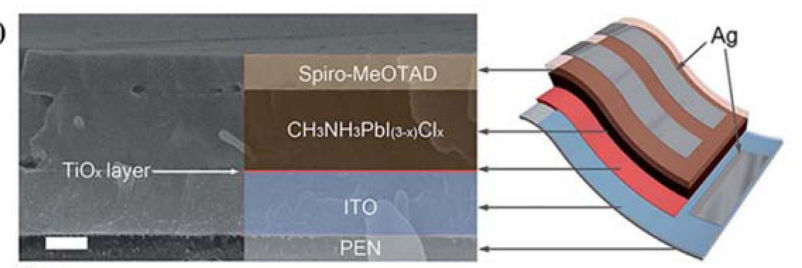

(b)

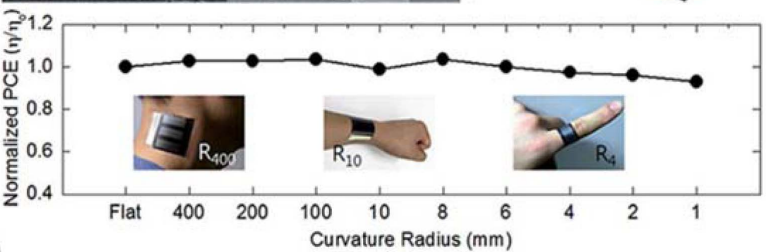

(c)

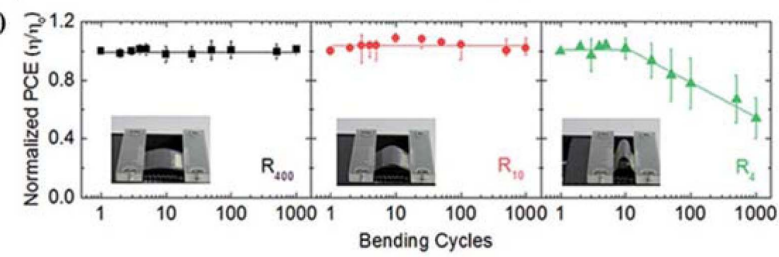

Fig. 1. (a) Cross-sectional SEM image and structure of the FPSCs. Scale bar: $200 \mathrm{~nm}$. (b) Normalized PCE measured after bending the substrate from a radius of 1 $\mathrm{mm}$ to a radius of $400 \mathrm{~mm}$. Inset: photographs of the FPSCs attached to a human neck, wrist, and finger, corresponding to $400 \mathrm{~mm}, 10 \mathrm{~mm}$ and $4 \mathrm{~mm}$ bending radii, respectively. (c) Normalized PCE of FPSCs as a function of number of bending cycles with radii of 400 $\mathrm{mm}, 10 \mathrm{~mm}$, and $4 \mathrm{~mm}$. The error bars represent the standard deviation of 4 tests. Inset: photographs of the bending tests. Reprinted with permission from ref. 40. Copyright 2015 Royal Society of Chemistry.

required to obtain high quality $\mathrm{TiO}_{2}$ for electron transport. This high-temperature process is incompatible with the low thermal stability of the flexible substrate. To overcome this, numerous strategies have been exploited for the preparation of $\mathrm{TiO}_{2}$ ETLs on ITO-PEN/PET substrates, including chemical sintering, ${ }^{36)}$ plasma-enhanced atomic layer deposition (PEALD), ${ }^{37,38)}$ chemical vapor deposition, ${ }^{39)}$ radio frequency magnetron sputtering deposition (RFMSD), ${ }^{40,41)}$ and electrophoretic deposition. ${ }^{42)}$ Atomic layer deposition is often used to deposit high-quality, stoichiometric, dense, pinholefree thin films.

In 2014, Jung and co-workers used low-temperature PEALD of a titanium(IV) isopropoxide precursor to deposit a $20 \mathrm{~nm}$ thick, amorphous, $\mathrm{cp}-\mathrm{TiO}_{\mathrm{x}}$ layer on a PEN/ITO substrate; the film was then annealed at $80^{\circ} \mathrm{C}$ for $15 \mathrm{~min}$, achieving a PCE of $12.2 \%$, a high efficiency for the planar configuration (Fig. 1). ${ }^{38)}$ In 2015, Brown and co-workers reported low-temperature, flexible PSCs with a mesoporous architecture; they used cyclopentadienyl alkylamido titanium, $\mathrm{Ti}(\mathrm{CpMe})\left(\mathrm{NMe}_{2}\right)_{3}$, as the precursor to deposit cp- $\mathrm{TiO}_{2}$ on PET/ITO substrates via PEALD; following this, spin coating was used to prepare mesoporous $\mathrm{TiO}_{2}$ scaffolds and the high-temperature annealing replaced by UV irradiation to remove the organic binders. These PSCs exhibited a PCE of $8.4 \%{ }^{43)}$ Liu's group used room-temperature RFMSD to 
(a)
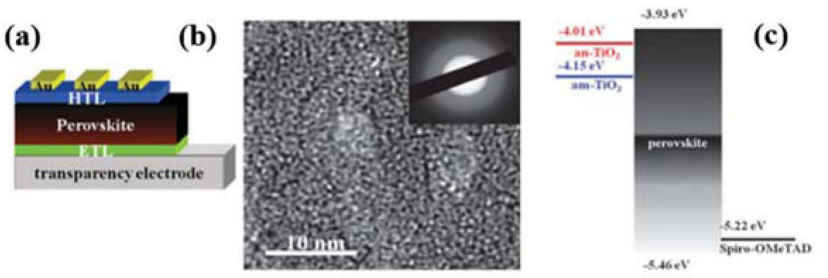

(d)

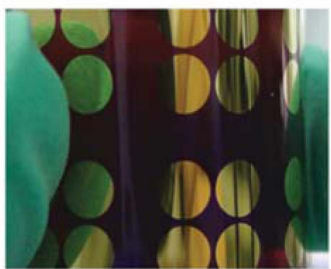

(f)
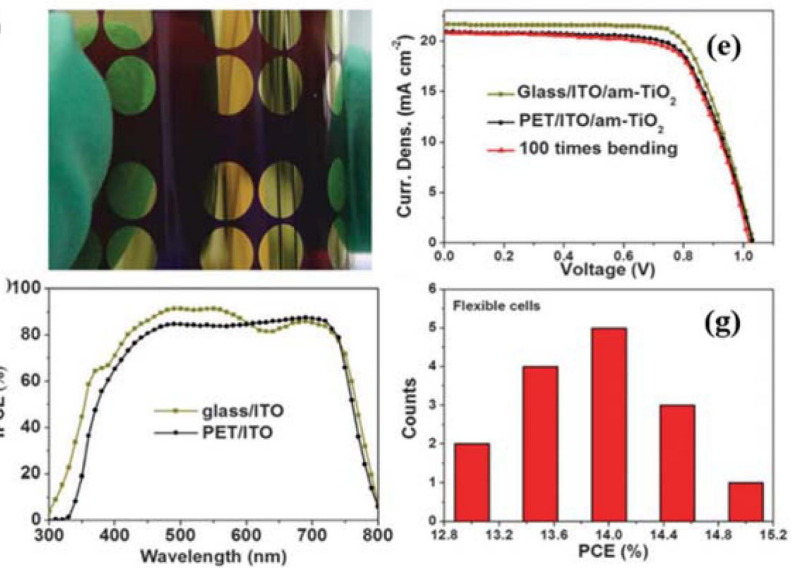

Fig. 2. (a) Structure of the planar PSCs. (b) HRTEM image and electron diffraction pattern (inset) of the asdeposited $\mathrm{TiO}_{2}$ film. (c) Energy-level diagram of the components of the PSCs with anatase $\mathrm{TiO}_{2}$ and am$\mathrm{TiO}_{2}$ ETLs. (d) Photograph of an FPSCs. (e) J-V curves of the rigid and flexible devices with an- $\mathrm{TiO}_{2}$ am- $\mathrm{TiO}_{2}$ ETL and the flexible device before and after 100 bending cycles. (f) IPCE curves of the rigid and flexible PSCs. (g) PCE distribution histogram for the FPSCs. Reprinted with permission from ref. 36 Copyright 2015 Royal Society of Chemistry.

deposit a dense, amorphous $\mathrm{TiO}_{2}\left(\mathrm{am}-\mathrm{TiO}_{2}\right)$ film to serve as an ETL in planar, flexible PSCs with efficiencies up to $15.07 \%{ }^{40)}$ The good performance of the ETL-based PSCs is attributed to improved electron extraction and reduced transfer resistance (Fig. 2).

Other inorganic and organic compounds used as ETLs in normally structured PSCs include $\mathrm{ZnO},{ }^{10,44,45)} \mathrm{WO}_{3}{ }^{46)}$ $\mathrm{In}_{2} \mathrm{O}_{3},{ }^{47)} \mathrm{CuInS}_{2},{ }^{47)} \mathrm{SnO}_{2},{ }^{48)} \mathrm{CdSe},{ }^{49)} \mathrm{Zn}_{2} \mathrm{SnO}_{4},{ }^{50,51)} \mathrm{Nb}_{2} \mathrm{O}_{5},{ }^{34)}$ and $\mathrm{C}_{60},{ }^{49)}$ which are synthesized at low temperatures. For instance, Liu's group used low-temperature electron-beam (a)

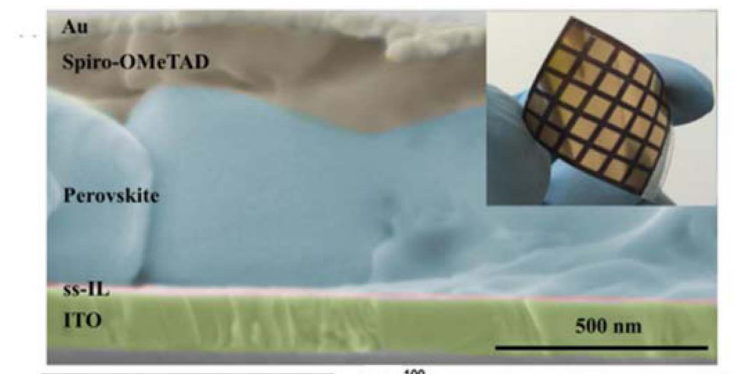

(b)
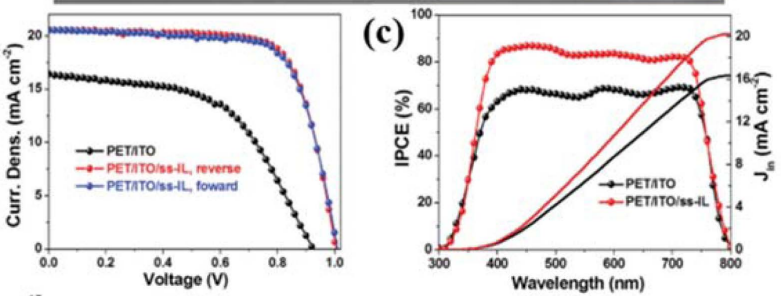

(d)
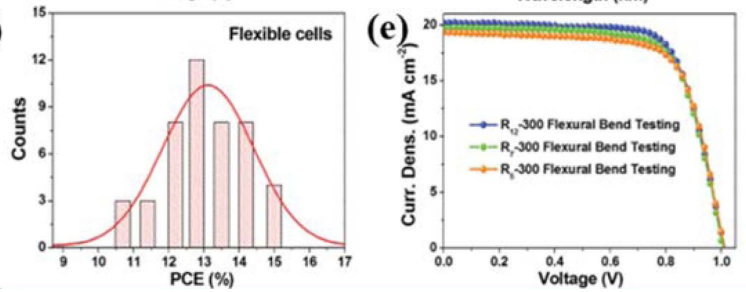

Fig. 4. (a) Cross-sectional view of a complete device based on ss-IL ETM. Inset: photograph of the FPSCs. (b) J-V curves and (c) IPCE plots of the FPSCs with and without the ss-IL ETM. (d) PCE distribution histogram of the FPSCs based on ss-IL ETM. (e) J-V curves of a device after bending at curvature radii of $12 \mathrm{~mm}, 7 \mathrm{~mm}$, and $5 \mathrm{~mm}$ for 300 cycles. Reprinted with permission from ref. 13. Copyright 2016 John Wiley \& Sons.

thermal evaporation to deposit a $\mathrm{Nb}_{2} \mathrm{O}_{5}$ thin film on a PET/ ITO substrate, and, thus, obtained PCEs of up to $14.6 \%$ for their planar, FPSCs (Fig. 3). ${ }^{34)}$ Yang et al. introduced solidstate ionic liquids (ss-ILs) (1-benzyl-3-methylimidazolium chloride) into planar-structured, flexible PSCs as ETLs, resulting in the highest PCE of $16.09 \%$ in publication year. ${ }^{13)}$ They attributed this excellent performance to the superior photoelectric properties, such as low reflectivity, high electron mobility, low trap density, and favorable work function, of the ss-IL ETL. The notorious hysteresis phe-
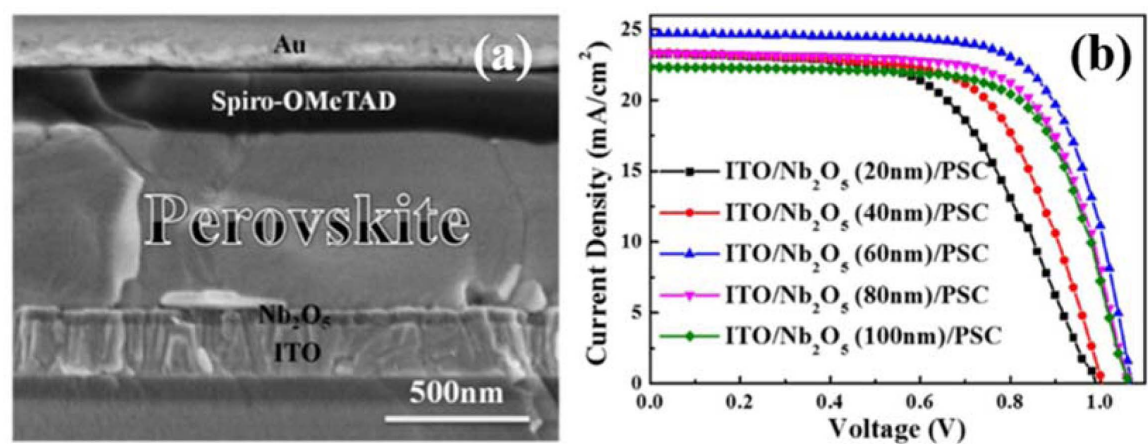

Fig. 3. (a) Cross-sectional SEM image of a PSCs device. (b) the effect of $\mathrm{Nb}_{2} \mathrm{O}_{5}$ thickness on the PSCs performance. Reprinted with permission from ref. 34. Copyright 2017 Elsevier. 

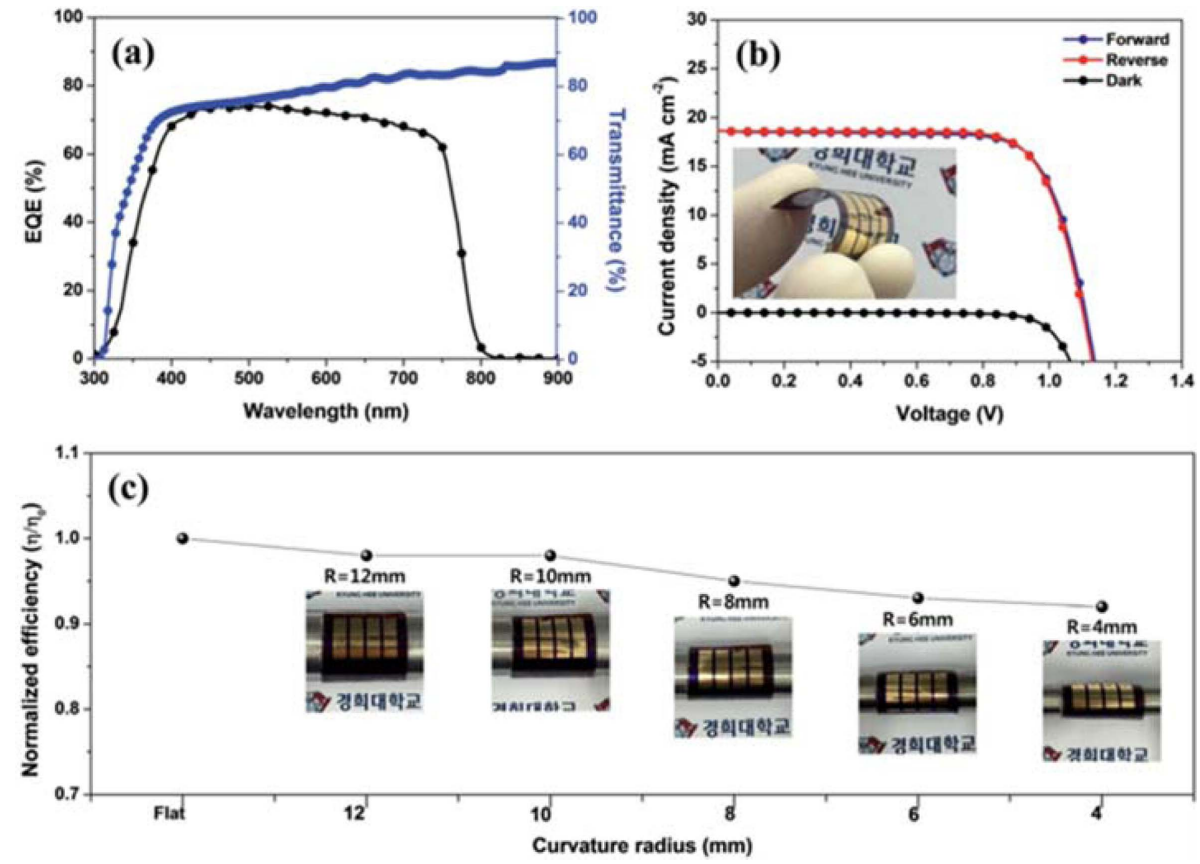

Fig. 5. (a) External quantum efficiency spectrum of the PEN/ITO/ZnO/MAPbI $/ 3$ PTAA/Au FPSCs and transmission spectrum of the PEN/ITO substrate. (b) J-V curves of FPSCs under illumination of 1 Sun. Inset: photograph of the FPSCs. (c) Normalized PCE of FPSCs at bending radius R. Reprinted with permission from ref. 45. Copyright 2016 Royal Society of Chemistry.

nomenon is almost eliminated by these attributes, and the devices show mechanical robustness after 300 cycles of repeated bending over different diameters (Fig. 4).

Owing to its wide band gap, high conductivity, facile solution processible, and thermal stability, $\mathrm{ZnO}$ has been extensively used in photovoltaic devices. For example, Kumar et $a l$. reported a conversion efficiency of $2.62 \%$ for normal FPSCs comprised of PET/ITO/ZnO/ZnO-rod/MAPbI $/ 3 /$ Spiro$\mathrm{OMeTAD} / \mathrm{Au},{ }^{44)}$ and Liu et al. reported a conversion efficiency of $10.2 \%$ for PET/ITO/ZnO/MAPbI $/$ /spiro-OMeTAD/ Ag FPSCs. ${ }^{10)}$ Yang's group developed a low-temperature $\left(150^{\circ} \mathrm{C}\right)$ spin-coating process to prepare highly transparent, uniform ZnO ETLs for FPSCs; after modification with urea, the perovskite film quality improved significantly, resulting in PCEs of up to $11.9 \% .^{52)}$ By spin-coating a $\mathrm{ZnO}$ nano-sol solution, Im's group prepared high quality $\mathrm{ZnO}$ thin films as an effective ETL for FPSCs; ZnO-based flexible devices fabricated on a PEN/ITO substrate achieved an average PCE of $15.5 \%$ and exhibited considerable mechanical stability (Fig. $5) .{ }^{45)}$

Other inorganic compounds can also be exploited in PSCs. Shin et al. reported conversion efficiencies of up to $15.3 \%$ for $\mathrm{PEN} / \mathrm{ITO} / \mathrm{Zn}_{2} \mathrm{SnO}_{4} / \mathrm{MAPbI}_{3} / \mathrm{PTAA} / \mathrm{Au}$ FPSCs. ${ }^{50)}$ They also reported that tailoring of the energy levels, by adjusting the $\mathrm{Zn}_{2} \mathrm{SnO}_{4} \mathrm{NPs}$ grain size, increased the efficiency to $16 \%$ under AM 1.5G illumination with an intensity of $100 \mathrm{~mW}$ $\mathrm{cm}^{-2}$ (Fig. 6). ${ }^{53)}$

Due to its large band gap, high transparency, and high carrier mobility, $\mathrm{SnO}_{2}$ has attracted significant attention as a potential replacement for $\mathrm{cp}-\mathrm{TiO}_{2}$ in PSCs. Miyasaka's

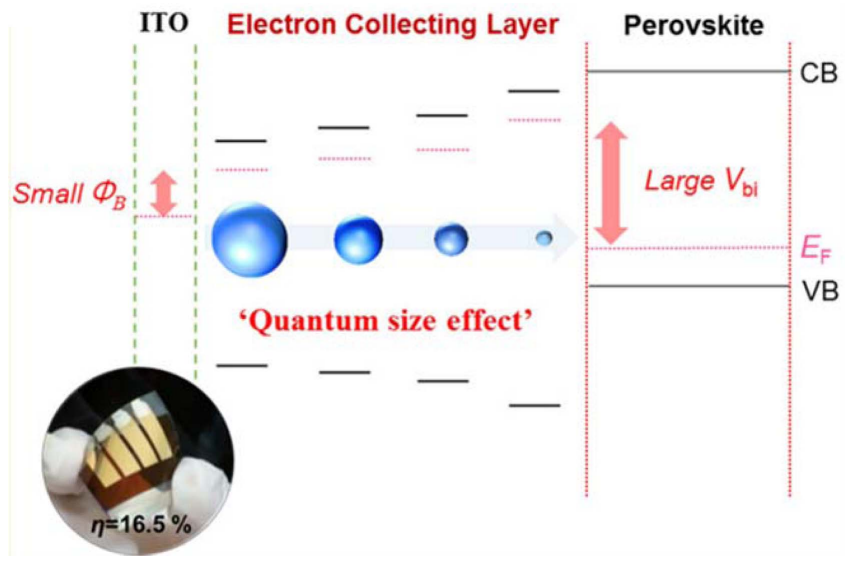

Fig. 6. Energy level diagram of FPSCs components with different size of $\mathrm{Zn}_{2} \mathrm{SnO}_{4}$ as ETL. Reprinted with permission from ref 53. Copyright 2016 American Chemical Society.

group used a mesoporous-brookite $\mathrm{TiO}_{2}$ layer, with amorphous $\mathrm{SnO}_{\mathrm{x}}$ as an ETL, deposited on an ITO/PEN substrate below $150^{\circ} \mathrm{C}$ to achieve PCEs of up to $13.4 \%$ and hysteresisfree J-V curves. ${ }^{54)}$ Yan's group reported the use of PEALD to prepare $\mathrm{SnO}_{2}$ thin films at $100^{\circ} \mathrm{C}$ on a PET/ITO flexible substrate; the efficiency up to $16.8 \%$ was obtained using $\mathrm{C}_{60}$ self-assembled-monolayer passivation of the $\mathrm{SnO}_{2}$ surface. ${ }^{48)}$ Despite the high efficiency, the as-deposited $\mathrm{SnO}_{2}$ film was not completely transformed, and organic residues were present. Thus, water vapor was introduced during the annealing process to facilitate completion of the reaction. 
(a)

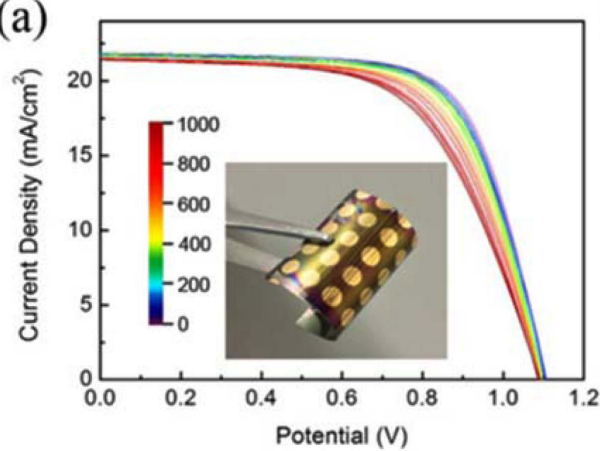

(b)

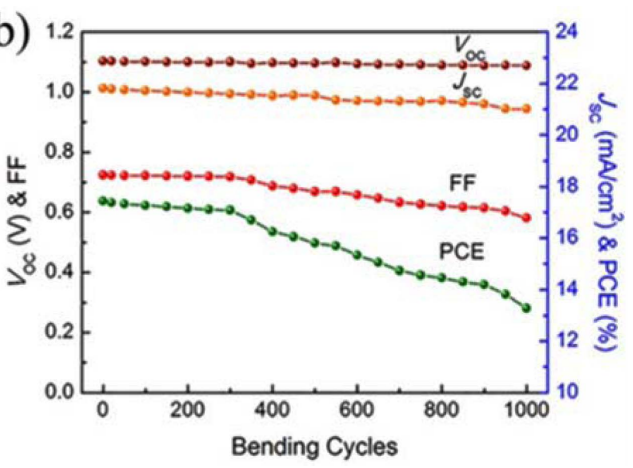

Fig. 7. Bend fatigue testing of a FPSCs over a bending radius of $1 \mathrm{~cm}$. (a) J-V curves measured after repeated bending cycles. (b) Performance parameters as a function of the number of bending cycles. Reprinted with permission from ref 2 . Copyright 2017 American Chemical Society.

With the water-vapor treatment, the electrical conductivity of the $\mathrm{SnO}_{2}$ film improved, and the resulting FPSCs exhibited dramatic improvements in $\mathrm{V}_{\mathrm{oc}}$ and $\mathrm{FF}$, no J-V hysteresis, and an increase in the PCE to $18.36 \%$; the highest reported efficiency for FPSCs with a regular architecture. They also exhibited mechanical robustness during 1000 cycles of repeated bending (Fig. 7). ${ }^{2)}$

\subsubsection{FPSCs based on the inverted architecture}

The need to withstand high temperatures, impedes the utilization of cp- $\mathrm{TiO}_{2}$ in FPSCs devices which prepared by conventional approaches; thus, most FPSCs based on ITO/ PET and PEN substrates are fabricated in the inverted planar architecture. In this configuration, poly(3,4-ethylenedioxythiophene) polystyrene sulfonate (PEDOT:PSS) is the most frequently used HTL, [6,6]-phenyl- $\mathrm{C}_{61}$-butyric acid methyl ester (PCBM) is the most popular ETL, and the whole device can be fabricated at under $150^{\circ} \mathrm{C}$. In 2013 , Snaith's group developed a device with a PET/ITO/ PEDOT:PSS/MAPbI ${ }_{3-\mathrm{x}} \mathrm{Cl}_{\mathrm{x}} / \mathrm{PCBM} / \mathrm{TiO}_{\mathrm{x}} / \mathrm{Al}$ structure and obtained a high PCE of $>6 \%{ }^{55)}$ In 2014, Lee's group introduced the copolymer tetrafluoroethylene-perfluoro-3,6-dioxa4-methyl-7-octene-sulfonic acid as an HTL for inverted FPSCs, resulting in PCEs as high as 8\%.56) In the same year, Bolink's group used Al-doped $\mathrm{ZnO}$ (AZO)/Ag/AZO coated PET as a flexible substrate, PEDOT:PSS and poly(4butylphenyldiphenylamine) as the HTM, and PCBM as ETM, displayed PCEs up to 7\% (Fig. 8(a)). ${ }^{57)}$ The important thing is that the PCE declines by only $0.1 \%$ after 50 bending cycles. In 2015, Kelly's group prepared high-conductivity, high-transmittance, high surface-coverage PEDOT on PET substrates to replace ITO, improving the mechanical properties of the FPSC device, and obtained a PCE over $7.6 \%$ and almost no hysteresis (Fig. 8(b)). ${ }^{58)}$

Although PEDOT:PSS is widely used as an HTM for inverted PSCs, its low conductivity hinders its development. Researchers have used surface modification and doping to improve its conductivity, and then increase FPSCs efficiency. Chen et al. prepared a self-assembled monolayer of 3-aminopropanoic acid on a PEDOT:PSS surface to modify (a)
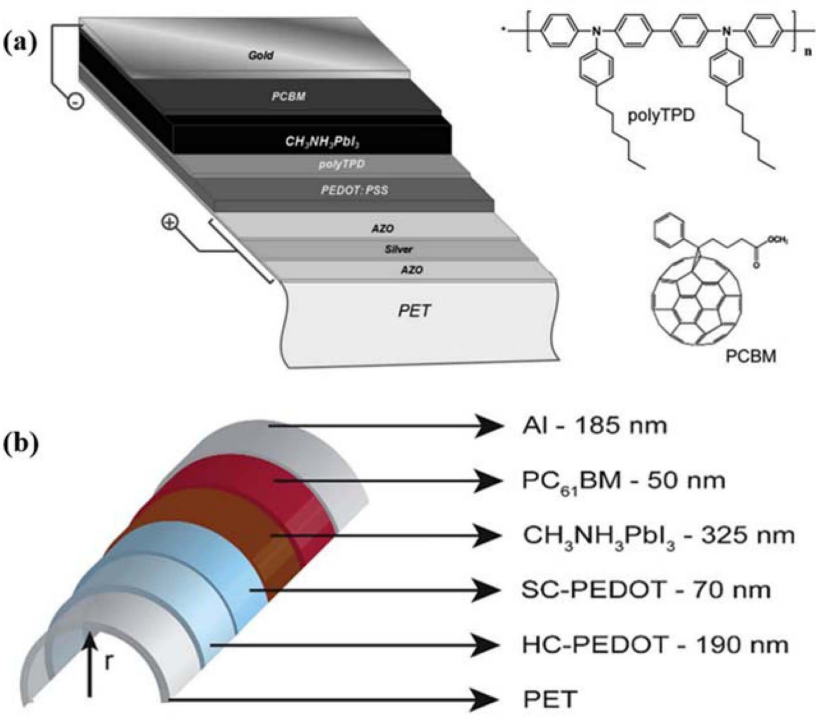

Fig. 8. (a) Schematic of the FPSCs and chemical structure of the materials used as the electron and hole blocking layers. Reprinted with permission from ref. 57. Copyright 2014 Royal Society of Chemistry. (b) Structure of the FPSCs, bent at a radius of curvature, $r$. Reprinted with permission from ref. 58. Copyright 2015 Royal Society of Chemistry.

the crystallinity and coverage of the perovskite film, resulting in an increase in PCE from $3.7 \%$ to $5.1 \% .{ }^{59)}$ Jang et al. introduced silver trifluoro-methanesulfonate (AgOTf) doped graphene oxide into PEDOT:PSS to improve the charge collection; FPSCs fabricated on a PET/ITO substrate showed a PCE of 9.67\%. ${ }^{60)}$ Bauer's group introduced a thin layer of $\mathrm{Cr}_{2} \mathrm{O}_{3}$ - $\mathrm{Cr}$ between the top metal electrode and the HTL, preventing diffusion of the metal and air into the perovskite film, which significantly increased device stability and achieved a high PCE of over 13\% and a power-per-weight of $23 \mathrm{~W} \mathrm{~g}^{-1}$. They successfully used these ultra-lightweight perovskite solar cell devices to power a model aircraft (Fig. 9). ${ }^{61)}$

$\mathrm{NiO}_{\mathrm{x}}$ is another frequently used HTM. Choy's group exploited spin-coating of an $\mathrm{NiO}_{\mathrm{x}}$ nanocrystal ink to develop 
(a)

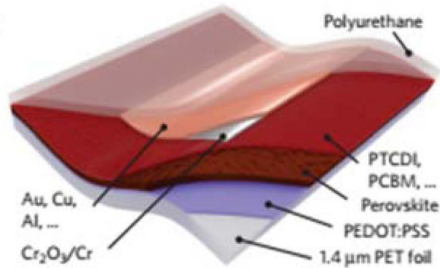

(d)

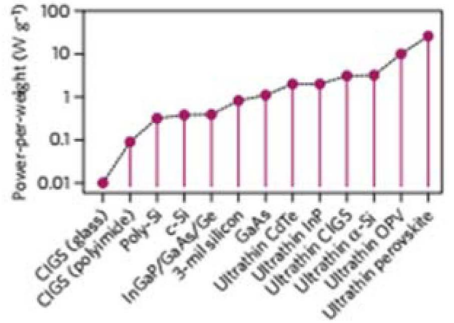

(f)

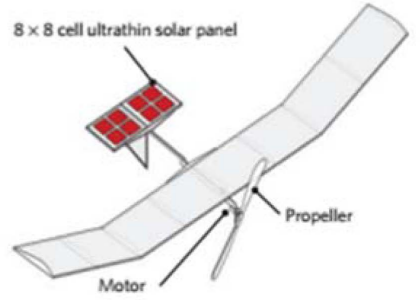

(h)

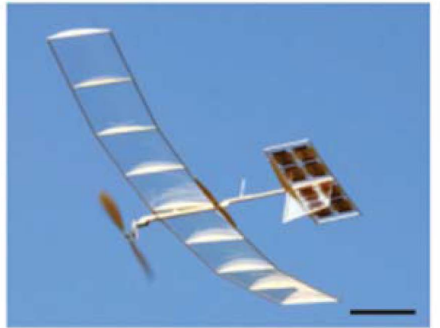

(b)

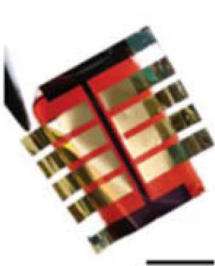

(c)

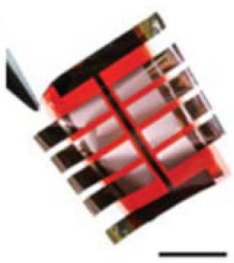

(e)

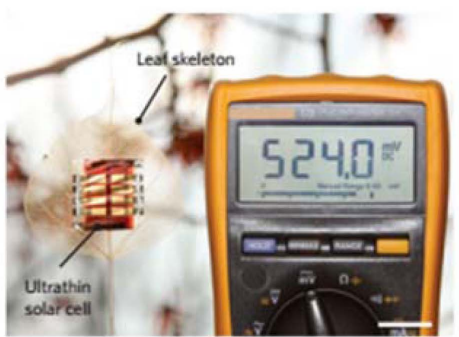

(g)

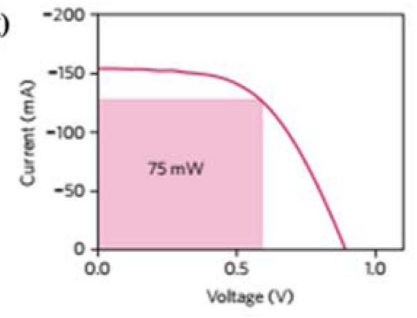

(i)

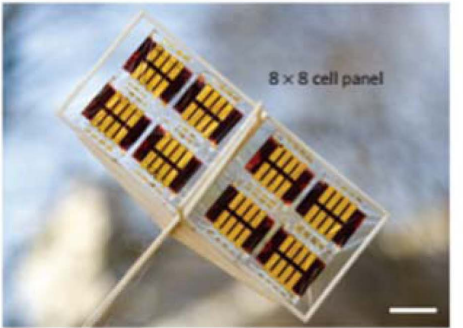

Fig. 9. (a) Schematic diagram of FPSCs. (b) and (c) photograph of FPSCs with gold and copper as top and back electrodes, respectively. Scale bar: $1 \mathrm{~cm}$. (d) The power-per-weight of different flexible solar cells. Ultrathin PSCs is more than double the nearest competing photovoltaic technology. (e) Dried leaf skeleton covered with a solar array of eight cells. The solar leaf (with a $100 \Omega$ load) delivers $\sim 2.75 \mathrm{~mW}$ under $\sim 30 \mathrm{klx}$ solar irradiance (Supplementary Movie 1). Scale bar: 2 $\mathrm{cm}$. (f) Schematic drawing of the solar-powered model airplane. The ultralight solar panel (red rectangles) is integrated into the horizontal stabilizers and powers a direct current (DC) motor with a propeller. (g) Power output of the 64-cell solar panel. Under simulated AM 1.5 solar irradiance, the panel outputs $75 \mathrm{~mW}$ at max power point and powers the DC motor of the model aircraft effectively under ambient outdoor illumination $(\sim 40 \mathrm{klx})$. (h) Snapshot of the model plane during solar-powered outdoor flight (Supplementary Movie 3). Scale bar: $10 \mathrm{~cm}$. (i) Close-up photograph of the horizontal stabilizer with integrated solar panels. Scale bar: $2 \mathrm{~cm}$. Reprinted with permission from ref. 61. Copyright 2015 Nature Publication Group.

a controllable route to surface-nanostructured $\mathrm{NiOx}$ for use as an HTM in FPSCs; the surface nanostructure provides a large interfacial area, effectively increasing hole extraction. Consequently, a remarkable efficiency of $14.53 \%$ was obtained (Fig. 10). ${ }^{62)}$ Shao's group developed a new technique to fabricate $\mathrm{NiOx}$ nanoparticles at $80^{\circ} \mathrm{C}$; the $\mathrm{NiO}_{\mathrm{x}}$ film, prepared by spin coating pre-synthesized $\mathrm{NiO}_{\mathrm{x}}$ nanoparticles onto a PEN/ITO substrate and baking at $130^{\circ} \mathrm{C}$, achieved a preliminary PCE of $13.43 \%$.

Other HTMs have also been developed and used in inverted FPSCs, including $\mathrm{Cu}_{\mathrm{y}} \mathrm{Cr}_{\mathrm{z}} \mathrm{O}_{2},{ }^{63)} \mathrm{CoN},{ }^{64)} \mathrm{CuI},{ }^{65)}$ and other synthesized inorganic and organic compounds.

In 2017, Fang's group used a $\mathrm{Cu}_{\mathrm{y}} \mathrm{Cr}_{\mathrm{z}} \mathrm{O}_{2}$ film as an HTM for flexible PSCs on a PET/ITO substrate prepared by the solgel method at temperatures as low as $140^{\circ} \mathrm{C}$ and achieved PCEs of up to $15.36 \%$ (Fig. 11). ${ }^{63)}$

In 2016, Ko and Son's group adopted 1,4-bis(4-sulfonatobutoxy)benzene and thiophene moieties ( $\mathrm{PhNa}-1 \mathrm{~T})$ as an HTL for inverted FPSCs, with initial PCE of up to $14.7 \%$ it can effectively enhance device performance, such as morphology, charge extraction, and, especially, mechanical properties. The PhNa-1T-based FPSC PCEs remained at 


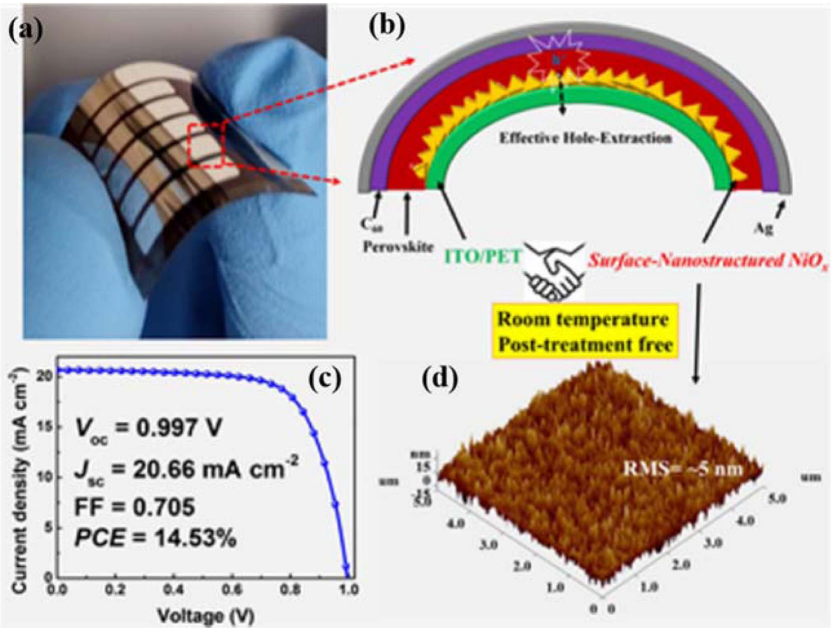

Fig. 10. (a) Photograph, (b) schematic diagram, (c) J-V curve, and (d) AFM image of FPSC devices fabricated on an NiOx coated PET/ITO substrate. Reprinted with permission from ref 62. Copyright 2016 American Chemical Society.

$60 \%$ of their initial values after 600 bending cycles (Fig. 12) ${ }^{66)}$ In 2017, Kang et al. fabricated a CoN film on an ITO/ PEN substrate, as an HTM for inverted PSCs, using roomtemperature vapor deposition and obtained an initial PCE of $10.2 \%$ (Fig. 13). ${ }^{64}$

\subsubsection{Electrodes}

The electrode is an integral and essential component of a
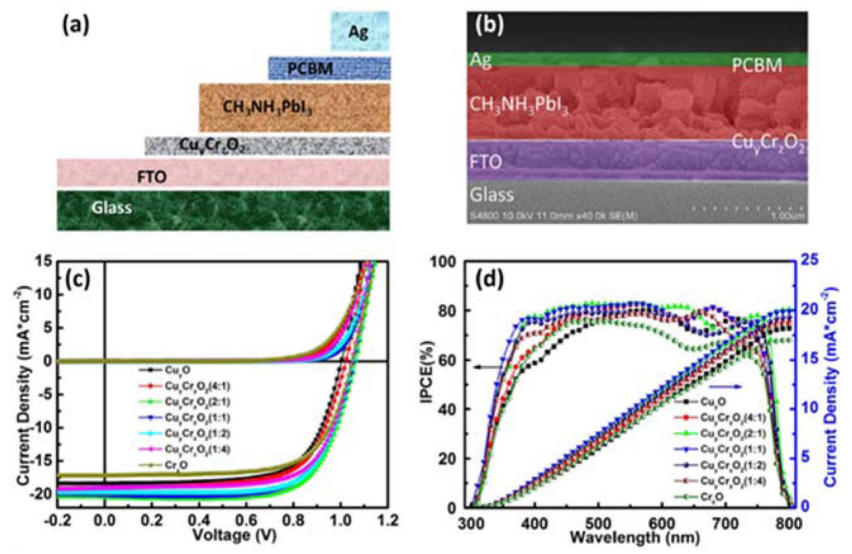

Fig. 11. (a) Schematic and (b) cross-sectional SEM image of a PSC using a $\mathrm{Cu}_{\mathrm{y}} \mathrm{Cr}_{\mathrm{z}} \mathrm{O}_{2}$ film. (c) Illuminated J-V characteristics, and (d) IPCE spectra (black) and the calculated integrated photocurrent (blue) of devices based on the $\mathrm{Cu}_{\mathrm{y}} \mathrm{Cr}_{\mathrm{z}} \mathrm{O}_{2}$ HTL films with different volume ratios $(\mathrm{y}: \mathrm{z}=1: 0,4: 1,2: 1,1: 1$, $1: 2,1: 4$, and $0: 1$ ). Measurements were carried out under illumination of 1 sun (AM $1.5 \mathrm{G}, 100 \mathrm{~mW}$ $\mathrm{cm}^{-2}$ ) with sweeping voltages in the scan-direction at a rate of $0.1 \mathrm{~V} \mathrm{~s}^{-1}$. The scans start and finish under forward bias, and have $2 \mathrm{~s}$ of stabilization time under illumination at forward bias prior to scanning. Reprinted with permission from ref 63 . Copyright 2017 John Wiley \& Sons.

PSC, which includes top electrode and bottom electrodes. Noble metals, such as $\mathrm{Au},{ }^{13,34)} \mathrm{Ag},{ }^{67)}$ and occasionally, $\mathrm{Al}^{68-70)}$ are used for the top electrode. TCO, such as ITO, FTO, and
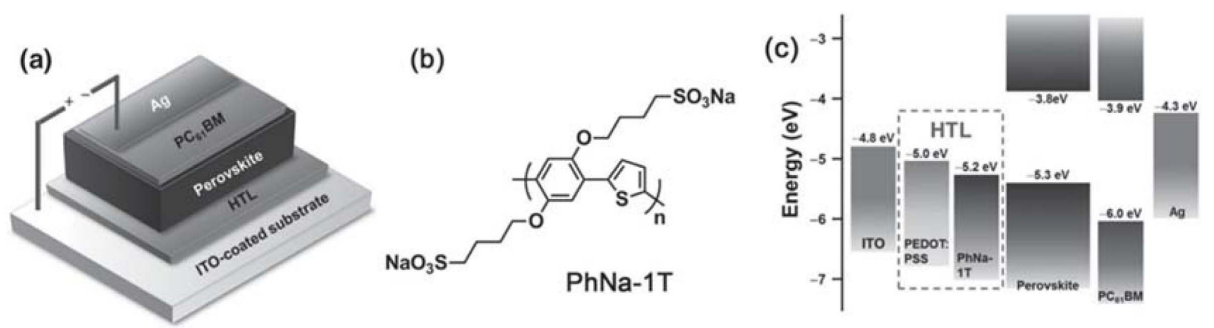

Fig. 12. (a) Device architecture of the planar PSC. (b) Chemical structure of PhNa-1T. (c) Schematic energy diagram of the PHJ PSC. Reprinted with permission from ref 66. Copyright 2016 John Wiley \& Sons.
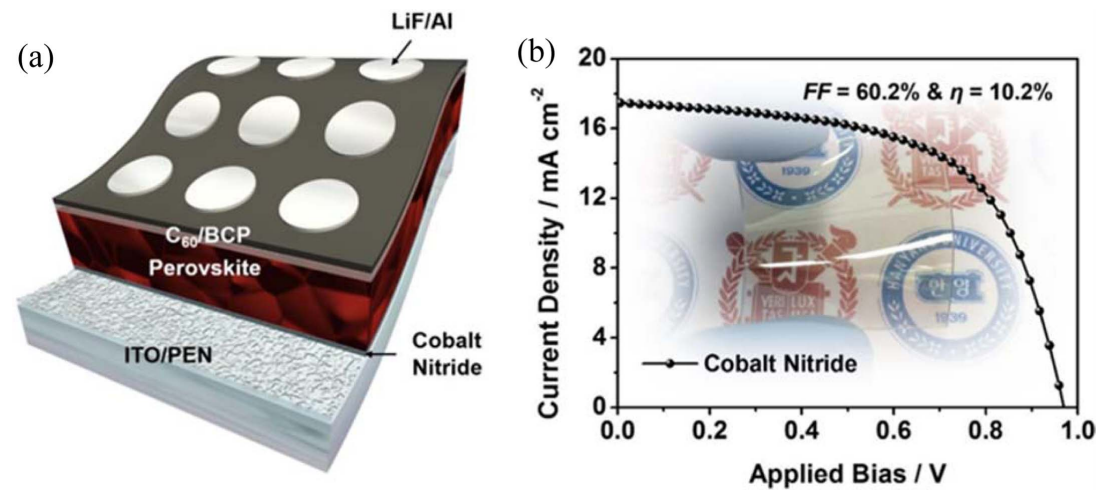

Fig. 13. Application of flexible perovskite solar cells. (a) Schematic illustration and (b) J-V characteristic of a flexible PSC comprising a CoN film deposited on a flexible ITO/PEN film as the HTL. Reprinted with permission from ref 64. Copyright 2018 John Wiley \& Sons. 

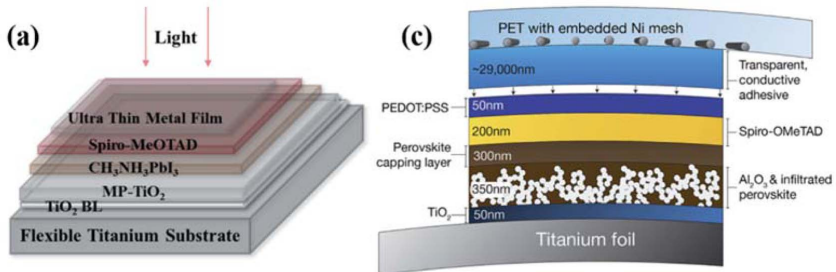

(b)

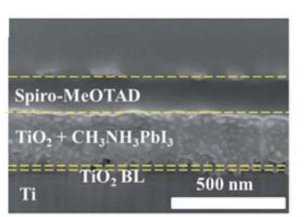

(d)

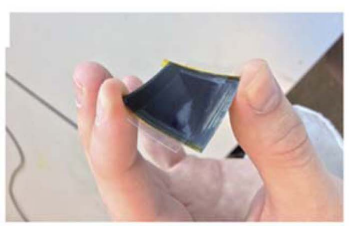

Fig. 14. (a) Structure of perovskite solar cell using a titanium ultra-thin metal foil substrate. (b) Cross-sectional image of the complete cells. J. Mater. Chem. $A, 2015,3$, 4129-4133. (c) Schematic representation of a metal-mounted perovskite solar cell and associated target-layer thicknesses. (d) Photograph of a flexible perovskite solar cell on titanium foil. (a-b) Reprinted with permission from ref 73 . Copyright 2015 Royal Society of Chemistry. (c-d) Reprinted with permission from ref. 74. Copyright 2015 Royal Society of Chemistry.

$\mathrm{AZO},{ }^{71,72)}$ are widely used as the bottom electrode. ITO is widely used as the bottom electrode in FPSCs deposited on PET and PEN polymer substrates. Although high efficiencies have obtained using PET and PEN/ITO bottom electrodes, the performance of the ITO films significantly decreases after repeated bending. Some studies have focused on overcoming this weakness by using metal foils to replace PET and PEN/ITO as the substrate and bottom electrode. In 2015, Jun's group fabricated semi-transparent FPSCs on $\mathrm{Ti}$ foil, the device structure is $\mathrm{Ti}$ foil $/ \mathrm{cp}-\mathrm{TiO}_{2} / \mathrm{mp}-\mathrm{TiO}_{2} /$ perovskite/Spiro/ultra-thin silver, and they showed PCE of over $6 \%$; the low efficiency was ascribed to the low transmittance of the Ag film (Fig. 14(a), (b)). ${ }^{73)}$ Watson's group overcame this issue using a PET/Ni-mesh top electrode tightly interwoven with PEDOT:PSS using a transparent conducting adhesive; both the transmittance and mechanical properties were improved, achieving a PCE of $10.8 \%$ (Fig. 14(c), (d)) ${ }^{74)}$ Ahmadi's group prepared FPSCs using copper foil both as

(b)

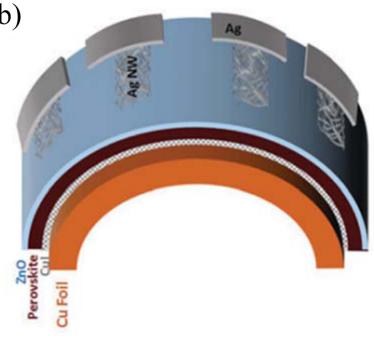

(b)

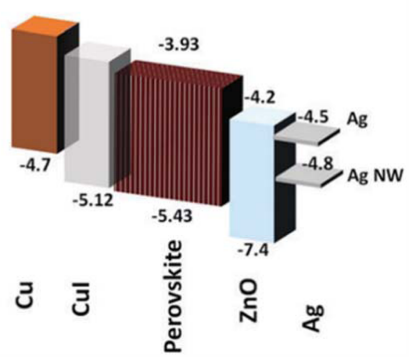

Fig. 15. (a) Schematic of the device architecture and (b) energy level diagram of a $\mathrm{Cu} / \mathrm{CuI} / \mathrm{CH}_{3} \mathrm{NH}_{3} \mathrm{PbI}_{3} / \mathrm{ZnO} /$ Ag FPSCs. Reprinted with permission from ref. 65. Copyright 2017 Royal Society of Chemistry.

the substrate and as the precursor for the CuI HTM; the device structure was $\mathrm{Cu} / \mathrm{CuI} /$ perovskite/ $\mathrm{ZnO} / \mathrm{Ag}$ nanowires, resulting in PCEs of up to $12.8 \%$ (Fig. 15) ${ }^{65)} \mathrm{Ag}$ nanowires have also been used as a bottom electrode. ${ }^{67,75,76)}$ For example, Choy's group reported the use of a room-temperature, solution-processed nano-composite, composed of a silver nano-network and graphene oxide film, as the bottom electrode for PSCs. Graphene oxide films not only improve the electron-extraction efficiency, but can also protect the silver network from liquid and gaseous halides. A PCE of 7.92\% was obtained. ${ }^{75)}$

Carbon nanomaterials are also used as electrodes in flexible PSCs. ${ }^{69,77,78)}$ In 2017, Jeon et al. used single-wall carbon nanotubes (SWNTs) as bottom electrodes for flexible PSCs. The device structure was PEN/SWNT/MoO $/ \mathrm{MEDOT}_{3} \mathrm{PSS} /$ perovskite/BCP- $\mathrm{C}_{60} / \mathrm{LiF} / \mathrm{Al}$; it exhibited high mechanical robustness and had a PCE of $11.0 \%$ (Fig. 16) ${ }^{77)}$ Guo and colleagues employed an $\mathrm{SnO}_{2}$-coated carbon nanotube $\left(\mathrm{SnO}_{2} @ \mathrm{CSCNT}\right)$ film as a top electrode for flexible PSCs. The device structure was $\mathrm{PEN} / \mathrm{ITO} / \mathrm{NiO}$-perovskite/ $\mathrm{Al}_{2} \mathrm{O}_{3}$ perovskite/ $\mathrm{SnO}_{2} @ \mathrm{CSCNT}$-perovskite, and they exhibited a PCE of $10.5 \%$; the device PCE remained at $91 \%$ of its original value after $550 \mathrm{~h}$ continuous illumination. ${ }^{78)}$ Choi's group used graphene as a bottom electrode for flexible PSCs. The device structure was $\mathrm{PEN} / \mathrm{Cr}-\mathrm{Au}-\mathrm{Al} / \mathrm{graphene/}$ $\mathrm{MoO}_{3} / \mathrm{PEDOT}: \mathrm{PSS} /$ perovskite/ $\mathrm{C}_{60} / \mathrm{BCP} / \mathrm{LiF} / \mathrm{Al}$, and the complete devices showed superb stability against bending,

(a)

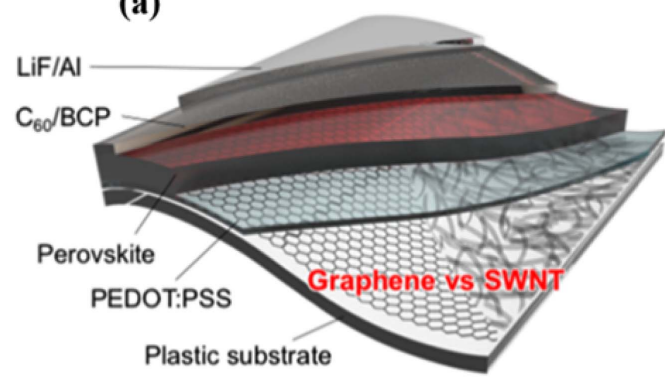

(b)

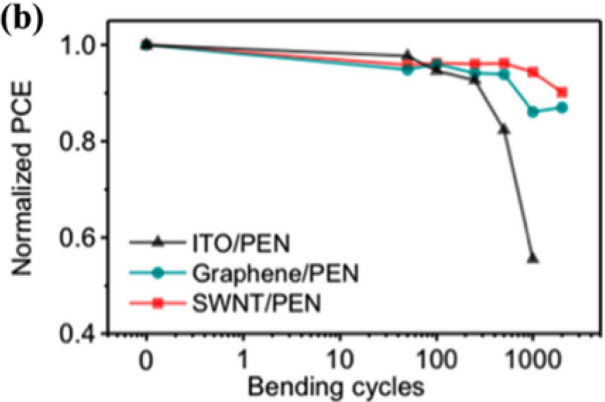

Fig. 16. (a) Schematic of the FPSCs using graphene and SWNTs on a PEN substrate. (b) Cyclic flexural test results for FPSCs using ITO/PEN (black), graphene/PEN (green), and SWNT/PEN (red) Reprinted with permission from ref. 77. Copyright 2017 American Chemical Society. 


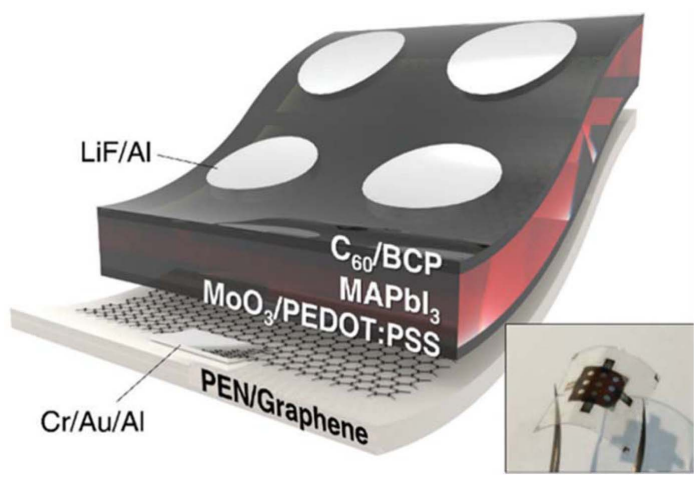

Fig. 17. Device structure of graphene-based FPSCs (inset: photograph of a complete device). Reprinted with permission from ref. 69. Copyright 2017 Royal Society of Chemistry.

maintaining $>90 \%$ of their initial efficiency after 1000 bending cycles and $85 \%$ after 5000 bending cycles (with a bending radius of $2 \mathrm{~mm}$ ) (Fig. 17). ${ }^{69)}$

\section{Conclusion and Outlook}

We have briefly summarized state-of-the-art FPSC structures, transport materials, and electrodes. PSCs are promising alternatives to silicon-based solar cells due to their superior optoelectrical properties, low-cost, and high-efficiency. They are especially promising as flexible solar cells, which are promising power solutions for future portable devices. Substantial work has been done to improve FPSCs performance; for example, exploiting low-temperature fabrication routes for high-efficiency metal-oxide electron/hole transport materials (e.g., $\mathrm{ZnO}, \mathrm{SnO}_{2}, \mathrm{Nb}_{2} \mathrm{O}_{5}$, and $\mathrm{NiO}_{\mathrm{x}}$ ); improving the conductivity of PEDOT:PSS via modification; improving the mechanical properties of flexible substrates (e.g., Ag nanowires, AZO/Ag/AZO, and HC-PEDOT:PSS coated PET substrates). Currently, the highest FPSCs PCE is $18.36 \%$, which was achieved with a PET/ITO substrate; however, the active area was only $0.08 \mathrm{~cm}^{2}$. In addition to the flexibility and efficiency, large scale and stability must also be considered. For large areas, methods including rollto-roll printing, slot-die coating, sequential vacuum deposition, doctor blade printing, and spray coating have been exploited, and are promising routes for the preparation of large-scale FPSCs. Several strategies have been used to improve FPSC stability, including introduction of inorganic transport materials, passivation of internal and surface defects of the perovskite film, and use of stable electrode materials. Currently, no device can exhibit high efficiency, large surface area, and high stability, even at laboratory scales. Therefore, large-scale, high-efficiency and stability of FPSCs remain an important research target, and more indepth research is necessary to achieve the aim of combing high efficiency, large surface area, and high stability into a single FPSCs.

\section{Acknowledgments}

This work was financially supported by the Global Frontier R\&D Program of the Center for Multiscale Energy Systems (2012M3A6A7054855), the Basic Science Research Program of the National Research Foundation of Korea (NRF-2014R1A4A1008474), a National Research Foundation of Korea grant funded by the Korean government (MSIP) (No. 2017R1A2B3010927), and the Future Materials Discovery Program (NRF-2016M3D1A1027664).

\section{REFERENCES}

1. N. R. E. Laboratory, Best Research-Cell Efficiencies, http:/ /www.nrel.gov/ncpv/images/efficiency_chart.jpg. Accessed on $09 / 04 / 2018$.

2. C. Wang, L. Guan, D. Zhao, Y. Yu, C. R. Grice, Z. Song, R. A. Awni, J. Chen, J. Wang, X. Zhao, and Y. Yan, "Water Vapor Treatment of Low-Temperature Deposited $\mathrm{SnO}_{2}$ Electron Selective Layers for Efficient Flexible Perovskite Solar Cells," ACS Energy Lett., 2 [9] 2118-24 (2017).

3. A. Kojima, K. Teshima, Y. Shirai, and T. Miyasaka, "Organometal Halide Perovskites as Visible-Light Sensitizers for Photovoltaic Cells," J. Am. Chem. Soc., 131 [17] 6050-51 (2009).

4. J. H. Im, C. R. Lee, J. W. Lee, S. W. Park, and N. G. Park, "6.5\% Efficient Perovskite Quantum-Dot-Sensitized Solar Cell," Nanoscale, 3 [10] 4088-93 (2011).

5. H. S. Kim, C. R. Lee, J. H. Im, K. B. Lee, T. Moehl, A. Marchioro, S. J. Moon, R. Humphry-Baker, J. H. Yum, J. E. Moser, M. Gratzel, and N. G. Park, "Lead Iodide Perovskite Sensitized All-Solid-State Submicron Thin Film Mesoscopic Solar Cell with Efficiency Exceeding 9\%," Sci. Rep., 2591 (2012).

6. M. M. Lee, J. Teuscher, T. Miyasaka, T. N. Murakami, and H. J. Snaith, "Efficient Hybrid Solar Cells Based on Meso-Superstructured Organometal Halide Perovskites," Science, 338 [6107] 643-47 (2012).

7. M. Liu, M. B. Johnston, and H. J. Snaith, "Efficient Planar Heterojunction Perovskite Solar Cells by Vapour Deposition," Nature, 501 [7467] 395-98 (2013).

8. N. J. Jeon, J. H. Noh, Y. C. Kim, W. S. Yang, S. Ryu, and S. I. Seok, "Solvent Engineering for High-Performance Inorganic-Organic Hybrid Perovskite Solar Cells," Nat. Mater., 13 [9] 897-903 (2014).

9. M. Xiao, F. Huang, W. Huang, Y. Dkhissi, Y. Zhu, J. Etheridge, A. Gray-Weale, U. Bach, Y. B. Cheng, and L. Spiccia, "A Fast Deposition-Crystallization Procedure for Highly Efficient Lead Iodide Perovskite Thin-Film Solar Cells," Angew. Chem., Int. Ed. Engl., 53 [37] 9898-903 (2014).

10. D. Y. Liu and T. L. Kelly, "Perovskite Solar Cells with A Planar Heterojunction Structure Prepared Using RoomTemperature Solution Processing Techniques," Nat. Photonics, 8 [2] 133-38 (2014).

11. N. Arora, M. I. Dar, A. Hinderhofer, N. Pellet, F. Schreiber, S. M. Zakeeruddin, and M. Gratzel, "Perovskite Solar Cells with CuSCN Hole Extraction Layers Yield 
Stabilized Efficiencies Greater than 20\%," Science, 358 [6364] 768-71 (2017).

12. W. Chen, Y. Z. Wu, Y. F. Yue, J. Liu, W. J. Zhang, X. D. Yang, H. Chen, E. B. Bi, I. Ashraful, M. Gratzel, and L. Y. Han, "Efficient and Stable Large-Area Perovskite Solar Cells with Inorganic Charge Extraction Layers," Science, 350 [6263] 944-48 (2015).

13. D. Yang, R. Yang, X. Ren, X. Zhu, Z. Yang, C. Li, and S. F. Liu, "Hysteresis-Suppressed High-Efficiency Flexible Perovskite Solar Cells Using Solid-State Ionic-Liquids for Effective Electron Transport," Adv. Mater., 28 [26] 520613 (2016).

14. P. W. Liang, C. Y. Liao, C. C. Chueh, F. Zuo, S. T. Williams, X. K. Xin, J. J. Lin, and A. K. Y. Jen, "Additive Enhanced Crystallization of Solution-Processed Perovskite for Highly Efficient Planar-Heterojunction Solar Cells," Adv. Mater., 26 [22] 3748-54 (2014).

15. H. P. Zhou, Q. Chen, G. Li, S. Luo, T. B. Song, H. S. Duan, Z. R. Hong, J. B. You, Y. S. Liu, and Y. Yang, "Interface Engineering of Highly Efficient Perovskite Solar Cells," Science, 345 [6196] 542-46 (2014).

16. J. X. Song, E. Q. Zheng, J. Bian, X. F. Wang, W. J. Tian, Y. Sanehira, and T. Miyasaka, "Low-Temperature $\mathrm{SnO}_{2}$ Based Electron Selective Contact for Efficient and Stable Perovskite Solar Cells," J. Mater. Chem. A, 3 [20] 1083744 (2015).

17. W. Y. Nie, H. H. Tsai, R. Asadpour, J. C. Blancon, A. J. Neukirch, G. Gupta, J. J. Crochet, M. Chhowalla, S. Tretiak, M. A. Alam, H. L. Wang, and A. D. Mohite, "HighEfficiency Solution-Processed Perovskite Solar Cells with Millimeter-Scale Grains," Science, 347 [6221] 522-25 (2015).

18. X. Li, D. Bi, C. Yi, J. D. Decoppet, J. Luo, S. M. Zakeeruddin, A. Hagfeldt, and M. Gratzel, "A Vacuum FlashAssisted Solution Process for High-Efficiency Large-Area Perovskite Solar Cells," Science, 353 [6294] 58-62 (2016).

19. W. S. Yang, B.-W. Park, E. H. Jung, N. J. Jeon, Y. C. Kim, D. U. Lee, S. S. Shin, J. Seo, E. K. Kim, J. H. Noh, and S. I. Seok, "Iodide Management in Formamidinium-LeadHalide-Based Perovskite Layers for Efficient Solar Cells," Science, 356 1376-79 (2017).

20. B. Susrutha, L. Giribabu, and S. P. Singh, "Recent Advances in Flexible Perovskite Solar Cells," Chem. Commun., 51 [79] 14696-707 (2015).

21. A. Banerjee, T. Su, D. Beglau, G. Pietka, F. S. Liu, S. Almutawalli, J. Yang, and S. Guha, "High-Efficiency, Multijunction nc-Si:H-Based Solar Cells at High Deposition Rate," IEEE J. Photovoltaics, 2 [2] 9-103 (2012).

22. A. Banerjee, F. S. Liu, D. B., T. Su, G. Pietka, J. Yang, and S. Guha, "12.0\% Efficiency on Large-Area, Encapsulated, Multijunction nc-Si:H-Based Solar Cells," IEEE J. Photovoltaics, 2 104-8 (2012).

23. X. Ren, W. Zi, Q. Ma, F. Xiao, F. Gao, S. Hu, Y. Zhou, and S. Liu, "Topology and Texture Controlled ZnO Thin Film Electrodeposition for Superior Solar Cell Efficiency," Sol. Energy Mater. Sol. Cells, 134 54-9 (2015).

24. W. Zi, X. Ren, F. Xiao, H. Wang, F. Gao, and S. Liu, "Ag Nanoparticle Enhanced Light Trapping in Hydrogenated Amorphous Silicon Germanium Solar Cells on Flexible
Stainless Steel Substrate," Sol. Energy Mater. Sol. Cells, 144 63-7 (2016).

25. S. Ishizuka, A. Yamada, K. Matsubara, P. Fons, K. Sakurai, and S. Niki, "Development of High-Efficiency Flexible $\mathrm{Cu}(\mathrm{In}, \mathrm{Ga}) \mathrm{Se}_{2}$ Solar Cells: A Study of Alkali Doping Effects on CIS, CIGS, and CGS Using Alkali-Silicate Glass Thin Layers," Curr. Appl. Phys., 10 [2] S154-56 (2010).

26. A. Chirila, S. Buecheler, F. Pianezzi, P. Bloesch, C. Gretener, A. R. Uhl, C. Fella, L. Kranz, J. Perrenoud, S. Seyrling, R. Verma, S. Nishiwaki, Y. E. Romanyuk, G. Bilger, and A. N. Tiwari, "Highly Efficient $\mathrm{Cu}(\mathrm{In}, \mathrm{Ga}) \mathrm{Se}_{2}$ Solar Cells Grown on Flexible Polymer Films," Nat. Mater., 10 [11] 857-61 (2011).

27. A. Romeo, G. Khrypunov, F. Kurdesau, M. Arnold, D. L. Bätzner, H. Zogg, and A. N. Tiwari, "High-Efficiency Flexible CdTe Solar Cells on Polymer Substrates," Sol. Energy Mater. Sol. Cells, 90 [18] 3407-15 (2006).

28. L. Kranz, C. Gretener, J. Perrenoud, R. Schmitt, F. Pianezzi, F. La Mattina, P. Blösch, E. Cheah, A. Chirilă, C. M. Fella, H. Hagendorfer, T. Jäger, S. Nishiwaki, A. R. Uhl, S. Buecheler, and A. N. Tiwari, "Doping of Polycrystalline CdTe for High-Efficiency Solar Cells on Flexible Metal Foil," Nat. Commun., 42306 (2013).

29. C. Lungenschmied, G. Dennler, H. Neugebauer, S. N. Sariciftci, M. Glatthaar, T. Meyer, and A. Meyer, "Flexible, Long-Lived, Large-Area, Organic Solar Cells," Sol. Energy Mater. Sol. Cells, 91 [5] 379-84 (2007).

30. S. I. Na, S. S. Kim, J. Jo, and D. Y. Kim, "Efficient and Flexible ITO-Free Organic Solar Cells Using Highly Conductive Polymer Anodes," Adv. Mater., 20 [21] 4061-67 (2008).

31. M. Kaltenbrunner, M. S. White, E. D. Głowacki, T. Sekitani, T. Someya, N. S. Sariciftci, and S. Bauer, "Ultrathin and lightweight Organic Solar Cells with High Flexibility," Nat. Commun., 3770 (2012).

32. T.-Y. Chen, Y.-J. Huang, C.-T. Li, C.-W. Kung, R. Vittal, and K.-C. Ho, "Metal-Organic Framework/Sulfonated Polythiophene on Carbon Cloth as a Flexible Counter Electrode for Dye-Sensitized Solar Cells," Nano Energy, 32 19-27 (2017).

33. Z. Xu, T. Li, Q. Liu, F. Zhang, X. Hong, S. Xie, C. Lin, X. Liu, and W. Guo, "Controllable and Large-Scale Fabrication of Rectangular CuS Network Films for Indium Tin Oxide and Pt-Free Flexible Dye-Sensitized Solar Cells," Sol. Energy Mater. Sol. Cells, 179 297-304 (2018).

34. J. S. Feng, Z. Yang, D. Yang, X. D. Ren, X. J. Zhu, Z. W. Jin, W. Zi, Q. B. Wei, and S. Z. Liu, "E-Beam Evaporated $\mathrm{Nb}_{2} \mathrm{O}_{5}$ as an Effective Electron Transport Layer for Large Flexible Perovskite Solar Cells," Nano Energy, 36 1-8 (2017).

35. Z. Zhu, Y. Bai, X. Liu, C. C. Chueh, S. Yang, and A. K. Jen, "Enhanced Efficiency and Stability of Inverted Perovskite Solar Cells Using Highly Crystalline $\mathrm{SnO}_{2}$ Nanocrystals as the Robust Electron-Transporting Layer," Adv. Mater., 28 [30] 6478-84 (2016).

36. H. C. Weerasinghe, P. M. Sirimanne, G. V. Franks, G. P. Simon, and Y. B. Cheng, "Low Temperature Chemically Sintered Nano-Crystalline $\mathrm{TiO}_{2}$ Electrodes for Flexible 
Dye-Sensitized Solar Cells,” J. Photochem. Photobiol., A, 213 [1] 30-6 (2010).

37. F. Di Giacomo, V. Zardetto, A. D'Epifanio, S. Pescetelli, F. Matteocci, S. Razza, A. Di Carlo, S. Licoccia, W. M. M. Kessels, M. Creatore, and T. M. Brown, "Flexible Perovskite Photovoltaic Modules and Solar Cells Based on Atomic Layer Deposited Compact Layers and UV-Irradiated $\mathrm{TiO}_{2}$ Scaffolds on Plastic Substrates," Adv. Energy Mater., 5 [8] 1401808 (2015).

38. B. J. Kim, D. H. Kim, Y.-Y. Lee, H.-W. Shin, G. S. Han, J. S. Hong, K. Mahmood, T. K. Ahn, Y.-C. Joo, K. S. Hong, N.-G. Park, S. Lee, and H. S. Jung, "Highly Efficient and Bending Durable Perovskite Solar Cells: Toward a Wearable Power Source," Energy Environ. Sci., 8 [3] 916-21 (2015).

39. H. C. Weerasinghe, F. Huang, and Y.-B. Cheng, "Fabrication of Flexible Dye Sensitized Solar Cells on Plastic Substrates," Nano Energy, 2 [2] 174-89 (2013).

40. D. Yang, R. X. Yang, J. Zhang, Z. Yang, S. Z. Liu, and C. Li, "High Efficiency Flexible Perovskite Solar Cells using Superior Low Temperature $\mathrm{TiO}_{2}$," Energy Environ. Sci., 8 [11] 3208-14 (2015).

41. S. S. Mali, C. K. Hong, A. I. Inamdar, H. Im, and S. E. Shim, "Efficient Planar n-i-p Type Heterojunction Flexible Perovskite Solar Cells with Sputtered $\mathrm{TiO}_{2}$ Electron Transporting Layers," Nanoscale, 9 [9] 3095-104 (2017).

42. L. Grinis, S. Kotlyar, S. Rühle, J. Grinblat, and A. Zaban, "Conformal Nano-Sized Inorganic Coatings on Mesoporous $\mathrm{TiO}_{2}$ Films for Low-Temperature Dye-Sensitized Solar Cell Fabrication," Adv. Func. Mater., 20 [2] 282-88 (2010).

43. F. D. Giacomo, V. Zardetto, A. D'Epifanio, S. Pescetelli, F. Matteocci, S. Razza, A. D. Carlo, S. Licoccia, W. M. M. Kessels, M. Creatore, and T. M. Brown, "Flexible Perovskite Photovoltaic Modules and Solar Cells Based on Atomic Layer Deposited Compact Layers and UV-Irradiated $\mathrm{TiO}_{2}$ Scaffolds on Plastic Substrates," Adv. Energy Mater., 5 [8] 1401808 (2015).

44. M. H. Kumar, N. Yantara, S. Dharani, M. Graetzel, S. Mhaisalkar, P. P. Boix, and N. Mathews, "Flexible, LowTemperature, Solution Processed ZnO-Based Perovskite Solid State Solar Cells," Chem. Commun., 49 [94] 1108991 (2013).

45. J. H. Heo, M. H. Lee, H. J. Han, B. R. Patil, J. S. Yu, and S. H. Im, "Highly Efficient Low Temperature Solution Processable Planar Type $\mathrm{CH}_{3} \mathrm{NH}_{3} \mathrm{PbI}_{3}$ Perovskite Flexible Solar Cells," J.Mater. Chem. A, 4 [5] 1572-78 (2016).

46. K. Wang, Y. Shi, Q. Dong, Y. Li, S. Wang, X. Yu, M. Wu, and T. Ma, "Low-Temperature and Solution-Processed Amorphous $\mathrm{WO}_{\mathrm{x}}$ as Electron-Selective Layer for Perovskite Solar Cells," J. Phys. Chem. Lett., 6 [5] 755-59 (2015).

47. J. You, Z. Hong, Y. Yang, Q. Chen, M. Cai, T.-B. Song, C.C. Chen, S. Lu, Y. Liu, H. Zhou, and Y. Yang, "Low-Temperature Solution-Processed Perovskite Solar Cells with High Efficiency and Flexibility," ACS Nano, 8 [2] 1674-80 (2014).

48. C. Wang, D. Zhao, C. R. Grice, W. Liao, Y. Yu, A. Cimaroli, N. Shrestha, P. J. Roland, J. Chen, Z. Yu, P. Liu, N.
Cheng, R. J. Ellingson, X. Zhao, and Y. Yan, "Low-Temperature Plasma-Enhanced Atomic Layer Deposition of Tin Oxide Electron Selective Layers for Highly Efficient Planar Perovskite Solar Cells," J.Mater. Chem. A, 4 [31] 12080-87 (2016).

49. L. Wang, W. F. Fu, Z. W. Gu, C. C. Fan, X. Yang, H. Y. Li, and H. Z. Chen, "Low Temperature Solution Processed Planar Heterojunction Perovskite Solar Cells with a Cdse Nanocrystal as an Electron Transport/Extraction Layer," J.Mater. Chem. C, 2 [43] 9087-90 (2014).

50. S. S. Shin, W. S. Yang, J. H. Noh, J. H. Suk, N. J. Jeon, J. H. Park, J. S. Kim, W. M. Seong, and S. I. Seok, "HighPerformance Flexible Perovskite Solar Cells Exploiting $\mathrm{Zn}_{2} \mathrm{SnO}_{4}$ Prepared in Solution Below 100 Degrees C," Nat. Commun., 67410 (2015).

51. S. S. Shin, W. S. Yang, E. J. Yeom, S. J. Lee, N. J. Jeon, Y. C. Joo, I. J. Park, J. H. Noh, and S. I. Seok, "Tailoring of Electron-Collecting Oxide Nanoparticulate Layer for Flexible Perovskite Solar Cells," J. Phys. Chem. Lett., 7 [10] 1845-51 (2016).

52. J. Zhou, X. Meng, X. Zhang, X. Tao, Z. Zhang, J. Hu, C. Wang, Y. Li, and S. Yang, "Low-Temperature Aqueous Solution Processed $\mathrm{ZnO}$ as an Electron Transporting Layer For Efficient Perovskite Solar Cells," Mater. Chem. Front., 1 [5] 802-6 (2017).

53. S. S. Shin, W. S. Yang, E. J. Yeom, S. J. Lee, N. J. Jeon, Y.-C. Joo, I. J. Park, J. H. Noh, and S. I. Seok, "Tailoring of Electron-Collecting Oxide Nanoparticulate Layer for Flexible Perovskite Solar Cells," J. Phys. Chem. Lett., 7 [10] 1845-51 (2016).

54. A. Kogo, M. Ikegami, and T. Miyasaka, "A $\mathrm{SnO}_{\mathrm{x}}$-Brookite $\mathrm{TiO}_{2}$ Bilayer Electron Collector for Hysteresis-Less High Efficiency Plastic Perovskite Solar Cells Fabricated at Low Process Temperature," Chem. Commun., 52 [52] 8119-22 (2016).

55. P. Docampo, J. M. Ball, M. Darwich, G. E. Eperon, and H. J. Snaith, "Efficient Organometal Trihalide Perovskite Planar-Heterojunction Solar Cells on Flexible Polymer Substrates," Nat. Commun., 42761 (2013).

56. K. G. Lim, H. B. Kim, J. Jeong, H. Kim, J. Y. Kim, and T. W. Lee, "Boosting the Power Conversion Efficiency of Perovskite Solar Cells Using Self-Organized Polymeric Hole Extraction Layers with High Work Function," Adv. Mater., 26 [37] 6461-66 (2014).

57. C. Roldan-Carmona, O. Malinkiewicz, A. Soriano, G. Minguez Espallargas, A. Garcia, P. Reinecke, T. Kroyer, M. I. Dar, M. K. Nazeeruddin, and H. J. Bolink, "Flexible High Efficiency Perovskite Solar Cells," Energy Environ. Sci., 7 [3] 994-97 (2014).

58. K. Poorkazem, D. Liu, and T. L. Kelly, "Fatigue Resistance of a Flexible, Efficient, and Metal Oxide-Free Perovskite Solar Cell," J. Mater. Chem. A, 3 [17] 9241-48 (2015).

59. Z. Gu, L. Zuo, T. T. Larsen-Olsen, T. Ye, G. Wu, F. C. Krebs, and H. Chen, "Interfacial Engineering of SelfAssembled Monolayer Modified Semi-Roll-to-Roll Planar Heterojunction Perovskite Solar Cells on Flexible Substrates," J. Mater. Chem. A, 3 [48] 24254-60 (2015). 
60. T. Liu, D. Kim, H. Han, A. R. Yusoff, and J. Jang, "FineTuning Optical and Electronic Properties of Graphene Oxide for Highly Efficient Perovskite Solar Cells," Nanoscale, 7 [24] 10708-18 (2015).

61. M. Kaltenbrunner, G. Adam, E. D. Glowacki, M. Drack, R. Schwodiauer, L. Leonat, D. H. Apaydin, H. Groiss, M. C. Scharber, M. S. White, N. S. Sariciftci, and S. Bauer, "Flexible High Power-Per-Weight Perovskite Solar Cells with Chromium Oxide-Metal Contacts for Improved Stability in Air," Nat. Mater., 14 [10] 1032-39 (2015).

62. H. Zhang, J. Cheng, F. Lin, H. He, J. Mao, K. S. Wong, A. K. Jen, and W. C. Choy, "Pinhole-Free and Surface-Nanostructured NiO Film by Room-Temperature Solution Process for High-Performance Flexible Perovskite Solar Cells with Good Stability and Reproducibility," ACS Nano, 10 [1] 1503-11 (2015).

63. P.-L. Qin, Q. He, C. Chen, X.-L. Zheng, G. Yang, H. Tao, L.-B. Xiong, L. Xiong, G. Li, and G.-J. Fang, "High-Performance Rigid and Flexible Perovskite Solar Cells with Low-Temperature Solution-Processable Binary Metal Oxide Hole-Transporting Materials," Sol. RRL, 1 [8] 1700058 (2017).

64. J. S. Kang, J.-Y. Kim, J. Yoon, J. Kim, J. Yang, D. Y. Chung, M.-C. Kim, H. Jeong, Y. J. Son, B. G. Kim, J. Jeong, T. Hyeon, M. Choi, M. J. Ko, and Y.-E. Sung, "Room-Temperature Vapor Deposition of Cobalt Nitride Nanofilms for Mesoscopic and Perovskite Solar Cells," Adv. Sci., 8 [13] 1703114 (2018).

65. B. Abdollahi Nejand, P. Nazari, S. Gharibzadeh, V. Ahmadi, and A. Moshaii, "All-Inorganic Large-Area LowCost and Durable Flexible Perovskite Solar Cells Using Copper Foil as a Substrate," Chem. Commun., 53 [4] 74750 (2017).

66. J. W. Jo, M.-S. Seo, M. Park, J.-Y. Kim, J. S. Park, I. K. Han, H. Ahn, J. W. Jung, B.-H. Sohn, M. J. Ko, and H. J. Son, "Improving Performance and Stability of Flexible Planar-Heterojunction Perovskite Solar Cells Using Polymeric Hole-Transport Material," Adv. Funct. Mater., 26 [25] 4464-71 (2016).

67. J. Han, S. Yuan, L. Liu, X. Qiu, H. Gong, X. Yang, C. Li, Y. Hao, and B. Cao, "Fully Indium-Free Flexible Ag Nanowires/ZnO:F Composite Transparent Conductive Electrodes with High Haze," J. Mater. Chem. A, 3 [10] 5375-84 (2015).

68. P. Docampo, J. M. Ball, M. Darwich, G. E. Eperon, and H. J. Snaith, "Efficient Organometal Trihalide Perovskite Planar-Heterojunction Solar Cells on Flexible Polymer Substrates," Nat. Commun., 42761 (2013).
69. J. Yoon, H. Sung, G. Lee, W. Cho, N. Ahn, H. S. Jung, and M. Choi, "Superflexible, High-Efficiency Perovskite Solar Cells Utilizing Graphene Electrodes: Towards Future Foldable Power Sources," Energy Environ. Sci., 10 [1] 337-45 (2017).

70. Y. Li, L. Meng, Y. M. Yang, G. Xu, Z. Hong, Q. Chen, J. You, G. Li, Y. Yang, and Y. Li, "High-Efficiency Robust Perovskite Solar Cells on Ultrathin Flexible Substrates," Nat. Commun., 710214 (2016).

71. C. Roldán-Carmona, O. Malinkiewicz, A. Soriano, G. Mínguez Espallargas, A. Garcia, P. Reinecke, T. Kroyer, M. I. Dar, M. K. Nazeeruddin, and H. J. Bolink, "Flexible High Efficiency Perovskite Solar Cells," Energy Environ. Sci., 7 [3] 994 (2014).

72. Q. Wei, Z. Yang, D. Yang, W. Zi, X. Ren, Y. Liu, X. Liu, J. Feng, and S. Liu, "The Effect of Transparent Conductive Oxide on The Performance $\mathrm{CH}_{3} \mathrm{NH}_{3} \mathrm{PbI}_{3}$ Perovskite Solar Cell without Electron/Hole Selective Layers," Sol. Energy, 135 654-61 (2016).

73. M. Lee, Y. Jo, D. S. Kim, and Y. Jun, "Flexible OrganoMetal Halide Perovskite Solar Cells on a Ti Metal Substrate," J. Mater. Chem. A, 3 [8] 4129-33 (2015).

74. J. Troughton, D. Bryant, K. Wojciechowski, M. J. Carnie, H. Snaith, D. A. Worsley, and T. M. Watson, "Highly Efficient, Flexible, Indium-Free Perovskite Solar Cells Employing Metallic Substrates," J. Mater. Chem. A, 3 [17] 914145 (2015).

75. H. Lu, J. Sun, H. Zhang, S. Lu, and W. C. Choy, "RoomTemperature Solution-Processed and Metal Oxide-Free Nano-Composite for the Flexible Transparent Bottom Electrode of Perovskite Solar Cells," Nanoscale, 8 [11] 5946-53 (2016).

76. D. G. Lee, D. Lee, J. S. Yoo, S. Lee, and H. S. Jung, "Effective Passivation of Ag Nanowire-Based Flexible Transparent Conducting Electrode by $\mathrm{TiO}_{2}$ Nanoshell," Nano Convergence, 3 [1] 20 (2016).

77. I. Jeon, J. Yoon, N. Ahn, M. Atwa, C. Delacou, A. Anisimov, E. I. Kauppinen, M. Choi, S. Maruyama, and Y. Matsuo, "Carbon Nanotubes versus Graphene as Flexible Transparent Electrodes in Inverted Perovskite Solar Cells," J. Phys. Chem. Lett., 8 [21] 5395-401 (2017).

78. Q. Luo, H. Ma, F. Hao, Q. Hou, J. Ren, L. Wu, Z. Yao, Y. Zhou, N. Wang, K. Jiang, H. Lin, and Z. Guo, "Carbon Nanotube Based Inverted Flexible Perovskite Solar Cells with All-Inorganic Charge Contacts," Adv. Func. Mater., 27 [42] 1703068 (2017). 